\title{
Impacts of Tourism on the Coastal Environment of South China Sea: Terrestrial Perspective
}

\author{
Egbuche C. T. ${ }^{1, ~}$, Nwaihu E. C. ${ }^{1}$, Umeojiakor A. O. ${ }^{1}$, Zhang Jia'en ${ }^{2}$, Okechukwu Ukaga ${ }^{3}$ \\ ${ }^{1}$ Department of Forestry and Wildlife Technology, School of Agriculture and Agricultural Technology, Federal University of Technology \\ Owerri, Nigeria \\ ${ }^{2}$ College of Agriculture, South China University of Agriculture Guangzhou, China \\ ${ }^{3}$ College of Food, Agriculture and Natural Resources, University of Minnesota Extension USA
}

\section{Email address:}

ctoochi@yahoo.co.uk (Egbuche C. T.)

\section{To cite this article:}

Egbuche C. T., Nwaihu E. C., Umojiakor A. O., Zhang Jia'en, Okechukwu Ukaga. Impacts of Tourism on the Coastal Environment of South China Sea: Terrestrial Perspective. Agriculture, Forestry and Fisheries. Special Issue: Environment and Applied Science Management in a Changing Global Climate. Vol. 4, No. 3-1, 2015, pp. 21-28. doi: 10.11648/j.aff.s.2015040301.14

\begin{abstract}
At recent times, Asia and the Pacific have been rated very high as major tourism destinations. This transdisciplinary (nature and social science concepts) study reveals that tourism activities generate pressure on forest ecosystems and coastal biodiversity. Dongguan forest (site) park attracted impact on terrestrial ecosystem with impact base respondent (9 000), while Shenzhen (18 000), Guangzhou (18 000) and Zhuhai (12 000) districts showed much higher values on general impact. A coastal activity survey and impact base of visitor response model evaluation was used. A general impact and causative platform were identified as driving fundamental (direct/indirect) factors in the region. Subjective and observed broad impacts were presented however; trampling had a major terrestrial impact on both ecosystems. Further investigation is needed to evaluate the economic impact of tourism in the region using industrial, urban and tourism potential factors after the 2008 Olympic Games in China. Strategies for appropriate action and government regulations are recommended concepts of terrestrial and coastal conservation planning and land use.
\end{abstract}

Keywords: Coastal Environment, Coastal Conservation, Terrestrial Ecology, South China Sea, Tourism Impact

\section{Introduction}

This paper is based on broad field investigations conducted on tourism potential impacts on the coastal environments of Guangdong province in the Peoples Republic of China. It addresses the issues of tourists' interaction with terrestrial, coastal ecosystems and the associated impact of such human interactions. We focused on the impact of tourism causative and platform in Dongguan forest park from a natural science perspective and in designated coastal districts from social science perspective. The increased recreational use of forest parks, coastal areas, and other protected areas has endangered areas of great ecological interest due to the negative effect of tourism platforms on local ecosystems and plant communities. [1] documented that tourism and outdoor recreation could lead to negative impacts on the environment due to pressures that stretch the natural capability of the ecosystems. Uncontrolled conventional approach to tourism poses a potential threat to the natural environment and biodiversity thereby tourism conducted along coastlines/beaches is bound to influence the ecosystems natural capacity [2]. Under tourism destination consequences, impact scenarios on platforms were considered under coastal (intertidal and forest park of individual (single) tourists and tour groups (group package) effect on plant species). We adopted the conceptual idea of natural science in taxonomic identification of forest species (amounting to 99 species) in the Dongguan forest park and applied social science methods to enumerate coastal ecotourism activities ( 9 subjective outdoor activities and impact base) in Guangdong province along the coast of the South China Sea. The potential positive effects of coastal ecotourism and forest park visits was considered, but overall tourism left evidence of negative environmental impact such as generating waste, pollution, and trampling 
of terrestrial ecosystems. Coastal recreation and forest parks have long been considered popular destinations for tourists and attract many tour groups [3]. Tourism and outdoor recreation is a human activity that may catalyze pollution and generate waste. It allows people to utilize, compete for, and modify natural resources. This study targets the impact of tourism activity when human population (consumers and potential beneficiaries) is concentrated in a certain geographical region (producer). Field assessments include the identification of forest park species, coastal tourism activity, and an assessment of the general impact on coastal environment/vegetation. Direct observations were employed which is study site scaling methods to document associated impact of tourism. Single site and group spot sites were identified as tourists destinations where [4] identified tourist destinations include public services and facilities, as well as physical and natural attractions, so tourist destinations are composed of (i) attractions, (ii) facilities and services, (iii) infrastructure, (iv) Hospitality and (v) cost variables. Destination tourism products comprise a set of tangible and non-tangible components based on an activity at the destination. [5] reported impact of tourism with varied activities that range from relatively innocuous pursuits to extremely popular sports all result in measurable deterioration of the world's coral ecosystems despite good management practices. Furthermore, [6], conducted visitor surveys for varieties of reasons but on the background that we considered coastal and forest parks as fragile ecosystems. Tourism activities that are conducted within forest parks and coastal districts may not substantially be of long-distance and duration [7] but may have significant ecological impact, especially from mass and packaged tour groups.

Increasing economic and industrial development both in developed and developing nations has created a higher volume of worldwide demand for recreation, leisure activities, and created the potential for even more tourism. Visits to seaside attractions are more prevalent in fast growing economic and industrial regions like Guangdong province exhibits critical issues of spatio-temporal development of international seaside tourism [8]. This concept results in development of tourism infrastructures, utilities and expanded urban growth, that could stretch (conurbation) towards coastal regions. Other important environmental impact of tourism are the conflicting and serious issues involving ownership and of who controls potential tourism properties/facilities, the local people, regional and national administration, and multiple policies/regulations such as land use competition, natural environment and infrastructures, [9]. Individual and group tourism in coastal areas lead to illegal structures and juxtapose seaside growth with garbage and "shanty towns". Generally, tourism is linked to contamination and degradation of ecologically valuable plant species (Such as mangrove), reduction of insect species, and seaside modification [10] and [11]. Coastal regions and their management, has been identified as posing multidisciplinary challenges [12]. Specifically, this study aimed to assess the following issues: (1) To understand the impacts of tourism on vegetation and (2) To assess tourism activity impact on coastal region like the South China Sea. This study objectively considers the direct impact of tourism on two levels: (1) that the outdoor recreation activities of both individual tourists and packaged tour groups have a multiple effect on terrestrial ecosystem and (2) that seaside (coastal) recreation and activities often generate pollution and waste.

\section{Study Area}

Guangdong province is located in the southern part of China and has a long coastline along the South China Sea. The province has a total area of 179,766 square kilometer. Key tributaries are rivers such as the Xijiang River, the Beijiang River, the Dongjiang River, the Hanjiang River, the Rongjiang River and the Moyangjiang River, which together form the Zhujiang River (Pearl River) as in fig. 1. The region has both tropical and sub-tropical climatic zones. The Tropic of Cancer runs through Guangdong Southwestern province. The region is generally warm and rainy all the year. The average annual rainfall is more than $1500 \mathrm{~mm}$, (rainy season is from April to September). The average temperature ranges from 19 to $26^{\circ} \mathrm{C}$. The province is endowed with a long coastline of about $3368 \mathrm{~km}$ along the South China Sea and additional coastline around an archipelago of 759 small islands (excluding Hong Kong, Macao and Dongsha Islands). The total land area of the archipelago accounts for only 1649 $\mathrm{km}^{2}$ and constitutes only $1.85 \%$ of the total land area of the province.

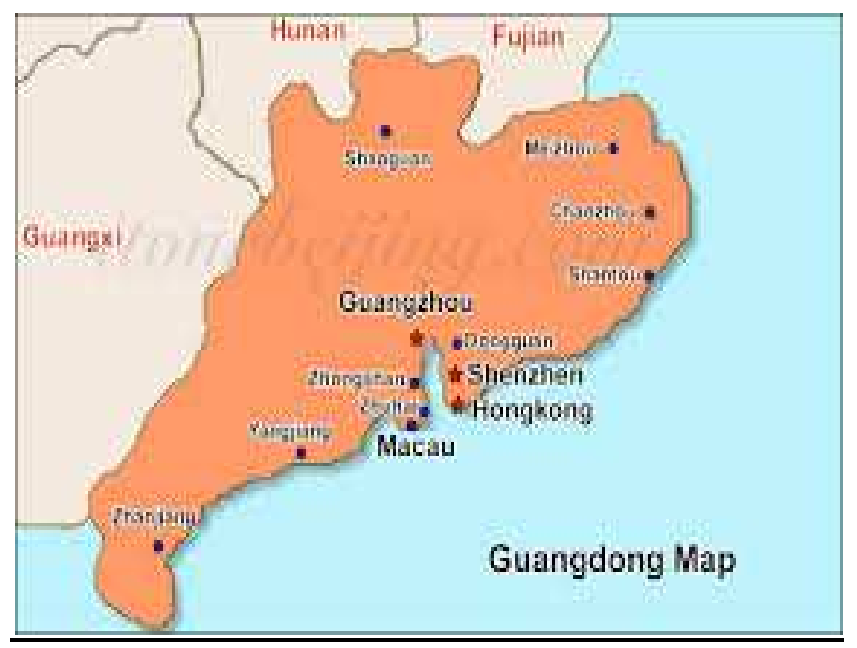

Fig. 1. South China Sea and geographical location of Guangdong province

\subsection{Data Source and Collection}

"Tourism Hot Spots" that attracts high volume of tourists for the activity impact survey include a) Dongguan Forest Park (Impact Survey on vegetation) and b) Popular tourist areas in Zhuhai, Xinhui, Jianmeng city, areas in Guangzhou and Shenzhen in coastal areas as shown in fig. 1 and 2. Then, 
primary data were collected through a field survey using Dillman's total design method [13]. Detailed questionnaires were administered to coastal tourists on their activities while on their stay at the destinations.

\subsection{Direct Impact of Individual Tourists and Packaged Group Tours on the Study Sites}

Direct impact data was collected from 1200 visitors to the Dongguan Forest Park and observed tourists activities in vulnerable coastal areas in the province. Two separate surveys were created with similarity in design, but with different objectives, tailored to identify tourist's activities that are associated with the area.

\subsection{Coastal Outdoor Activity Identification}

Coastal areas and beaches are popular for swimming and other water sports. This study is in agreement that beaches constant changing environment because of weather (storm impact), beach nourishment, pollution and development. Considering this background, each visitor was asked to identify/enumerate specific activities being conducted while on the visit. The enumeration forms were used to create activity profile that was assessed to identify the environmental impact associated with each activity. Figure 2 shows viable site surveys along the coastal areas - Zhuhai (300), Xinhui (100), Jianmeng city (100), Guangzhou (200) and Shenzhen (300) and Dongguan Forest Park (200) and the environment impact on each site.

\subsection{Environmental Impact Assessment}

Utilizing field activity response datasheet, direct impact was derived from each location by cumulative tourist's responses. Regional impact is the total spot across the study region (constant), spot impact is the number of hotspots adopted in each district (multiplier), and the summation produces the estimated total impact. This application has been utilized mostly in evaluating economic impact with IMLAN software. We adopted a simplified approach with this application because it allows for a direct field variable multiplication for every district and avoids overestimations unless the spot impact (multiplier) changes. Induced effects are not considered because of the nature of outdoor visits which last for a specific (short time). This model has been widely used by [14] of the Department of Agricultural Economics at Oklahoma State University. Their application was extensively used with multiple multipliers for the economic evaluation of participants' impact on the Summer Games held each May on the campus of Oklahoma State University [15]. We thereby applied the following simplified formula:

$$
L A C=\sum D I * R I * M I \Rightarrow T I
$$

Where:

LAC is location based on activity categories

$\sum$ is the summation of observed variables

DI is direct impact based on an active tourist's response

$\mathrm{RI}$ is the total number of assessed spots along the region (constant)

MI is the regional impact based on the hotpots of a district

$\mathrm{TI}$ is the grand total of tourism impact in the region

\subsection{Trampling Impact of Tourism on Vegetation}

On-the-spot- effect of tourists trampling and cutting in some common forest communities in Dongguan Forest Park was prominent, although such action was identified in other coastal districts of the region. The enumeration of species was conducted and established a spread sheet that identified 99 plant species. Vulnerability to plant disturbance among plant communities were in terms of (1) direct trampling and cutting of plant shoots and flowers, (2) changes in ground vegetation cover of the site, (4) soil compaction, and (4) litter.

\subsection{Analysis of Data}

Microsoft and other computer based packages were used in describing field and on spot observed data. The classification and division of plant species into groups facilitate the description of community assemblages and overlap within the grid system across the entire site. The variations were identified using the grid ordination, thus providing a complete vegetation data assemblage. [16].

\section{Results}

\subsection{Direct Observed Impact of Tourism}

Direct field observation and assessment within the regional (districts) designated tourism hotspot inventory survey using cumulative factors showed Shenzhen district (18 000), Guangzhou (18 000) and Zhuhai (12 000), respectively showed significantly high environmental impact from tourism based on recreational impact platform, geographical comparative advantage, and urban/industrial development base factors. This is shown in table 1, below, which ordinarily portrays specific districts to regional impact base value. Table 1 informs us that various categories of environmental impact were recorded and well observed in each study district exhibit associated and peculiar activity impact. However, Dongguan still maintains a high impact level in respect to plant species impact and industrial influences. 
Table 1. Direct location impact of tourism along South China Sea of Guangdong province

\begin{tabular}{|c|c|c|c|c|c|}
\hline $\begin{array}{l}\text { Location/ district } \\
\text { along the region }\end{array}$ & Impact inventory/ Category (LAC) & $\begin{array}{l}\text { Regional impact- } \\
\text { hotspot (RI) }\end{array}$ & $\begin{array}{l}\text { Spot impact } \\
\text { (Multiplier) (MI) }\end{array}$ & $\begin{array}{l}\text { Direct impact } \\
\text { by response (DI) }\end{array}$ & $\begin{array}{l}\text { Total impact } \\
\text { value (TI) }\end{array}$ \\
\hline Dongguan district & $\begin{array}{l}\text { Solid wastes, noise, trampling, species } \\
\text { degradation, transport }\end{array}$ & 20 & 3 & 150 & 9000 \\
\hline Xinhui district & $\begin{array}{l}\text { Wetland-impact, trampling,-solid wastes,- } \\
\text { fishing /boating modification }\end{array}$ & 20 & 3 & 100 & 6000 \\
\hline Shenzhen district & $\begin{array}{l}\text { Emissions, noise, beach-litter, solid- } \\
\text { industrial-wastes, transport,-coastal } \\
\text { modification, overcrowding }\end{array}$ & 20 & 4 & 300 & 18000 \\
\hline Jiameng city district & $\begin{array}{l}\text { Hot-spring degradation, plant species, } \\
\text { population, solid wastes, modifications }\end{array}$ & 20 & 3 & 100 & 6000 \\
\hline Guangzhou district & $\begin{array}{l}\text { Industrial noise, pollution, coastal } \\
\text { degradation, modification of landscape, } \\
\text { microbiological, ecological and } \\
\text { environmental hygiene and insecurity }\end{array}$ & 20 & 3 & 300 & 18000 \\
\hline Zhuhai district & $\begin{array}{l}\text { coastal modification/aesthetic-quality,- } \\
\text { overcrowding, resource degradation }\end{array}$ & 20 & 4 & 150 & 12000 \\
\hline
\end{tabular}

LAC - Location/ Impact inventory category based on environmental platform. DI - Direct impact based on visitors' activity response. RI - Total number of tourism hotspots along the districts (constant). MI - Multiplier impact base on a district potential attraction of visitors. TI - Grand total impact

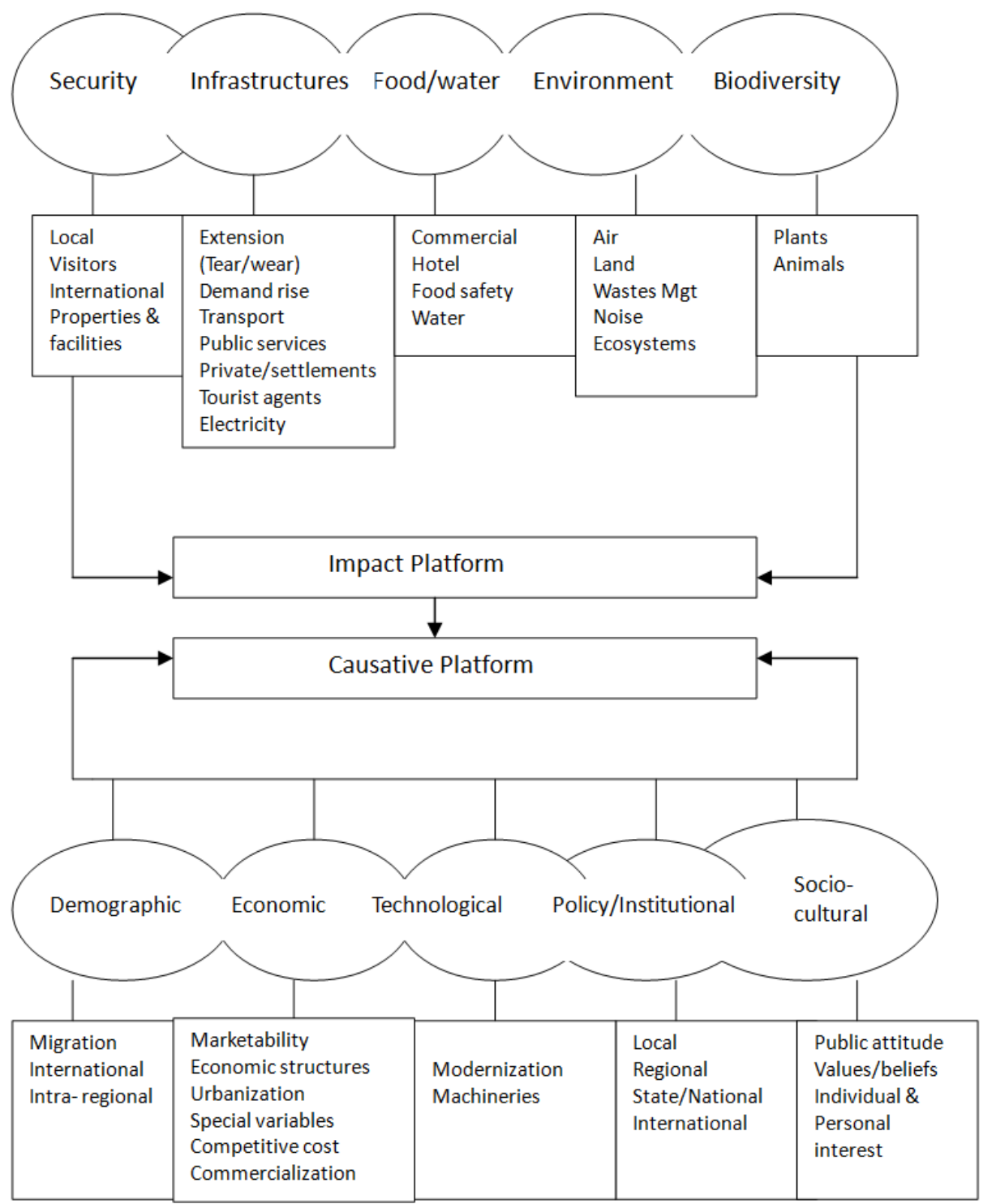

Fig. 2. Causative/impact platform of broad cluster of underlying driving and fundamental platform underpin the proximate impact of tourism identified directly and indirectly along the region. 


\subsection{Causative/Impact Platform of Broad Cluster}

Field assessment of tourism among ecosystems indicated broad causative and subjective impact (fig.2) that is associated with direct and indirect impact of tourism activities. Security of tourists is an important factor. Movement of people and properties originating from local and international platforms requires measures to protect the environment. Infrastructure is critical for effective tourism practices ranging from food consumption, utilization of public utilities, energy and waste removal to conservation of scarce resources. The constant wear and tear on the environment caused by tourist activities hampers rehabilitation and modifies the environment. The utilization of commercial and environmental properties becomes a source of degradation to the ecosystem and pollution to the environment. The natural biodiversity especially among fragile ecosystems has been directly impacted by tourism practices. In generally, causative platforms like demographic characteristics that involve local, regional and international structures are considered. Economic interplay within urban and rural interface leading to commercialization of economic goods brings into play competition and the high cost of special variables. Technological development becomes a catalyst for equipment, machinery, and modernization to support tourism activities.

\subsection{General Impact on the Coastal Environment of the Region}

Subjective platforms identified in forest parks and coastal regions (Table 2) underpinned the depletion of coastal natural and water resources, and local, land/vegetation. The platforms attract pollution in coastal areas. Furthermore, marine development affected depletion of the coral reefs (subjective platform) identified in the region. Field observation revealed greater demand and consumption of coastal and sea resources, such as fishes and activities (boat, swimming etc). There are observed scramble for local food, artisan materials, high demand for technical facilities. These observed factors results to contamination, scenic landscape modification. We observed higher demand for housing, both for commercial and accommodation which correspondingly increases generation of waste, emission from public services and transportation. Generally, all these factors increase impact on both lands, coastal and marine ecosystems.

Table 2. General impact on the coastal environment of the study region

\begin{tabular}{|c|c|}
\hline $\begin{array}{l}\text { Subjective platform of the } \\
\text { ecosystem }\end{array}$ & Observed broad impact \\
\hline $\begin{array}{l}\text { Depletion of coastal natural } \\
\text { and water resources }\end{array}$ & $\begin{array}{l}\text {-1 Increased consumption of especially scarce resource } \\
\text {-2 Overuse of water resources } \\
\text {-3 Degradation of water supplies and increase waste of in fresh water. }\end{array}$ \\
\hline Coastal local resources & $\begin{array}{l}\text {-1 Generates pressure on local resources like energy, food, and other raw materials. } \\
\text {-2 Greater extraction and transport physical intensity. } \\
\text {-3 High demand for tourists' facilities and technology. }\end{array}$ \\
\hline Coastal pollution impact & $\begin{array}{l}\text {-1 Coastal industries } \\
\text {-2 Air emissions and noise } \\
\text {-3 Solid waste and littering } \\
\text {-4 Release of sewage - sewage pollution results to public health problems (human and coastal animals). } \\
\text {-5 Cause discharge of oil and chemicals } \\
\text {-6 Visual pollution/modification, aesthetic pollution resulting to lack of planning and encourage sprawl of facilities. }\end{array}$ \\
\hline $\begin{array}{l}\text { Marine Development } \\
\text { Coral reefs }\end{array}$ & $\begin{array}{l}\text { - Breakwater channels and change in currents and coastlines } \\
\text { - May alter and destabilize fragile marine ecosystems, shoreline, anchoring, ships grounding, diving, yachting and cruising }\end{array}$ \\
\hline
\end{tabular}

Based on www.uneptie.org/pc/tourism/sus-tourism/env

\subsection{Physical Impacts - Impact of Trampling in Forest Park and Coastal Regions}

The effect of trampling was critically observed in Dongguan forest park and also observed to be a common impact factor on the soil in coastal areas, as shown below in table 3. The observations were notable in most areas trampled upon by visitors and collection of flowers and shoots. Species composition and coastal soil porosity impact were seriously observed in the region as supported by table 3 .

Table 3. showing trampling impact on coastal vegetation and soil/environment

\begin{tabular}{ll}
\hline Trampling on coastal vegetation & Trampling on soil and coastal environment \\
\hline Breaks and bruises vegetation, especially stems and shoots & Loss of soil organic matter \\
Cause reduction in plant vigor & Reduce coastal soil macro porosity \\
Results in poor and reduction of regeneration & Results in poor air and water permeability \\
Reduces and loss of ground cover & Increase water run off \\
Reduces and changes species composition & Accelerate coastal erosion \\
\hline
\end{tabular}




\section{Discussion}

\subsection{Relationship Between the Environment and Tourism Activities}

There exists a complex relationship between natural and manmade environments in regard to outdoor recreation and coastal tourism. This investigation revealed that tourism, by both induced and direct interaction, can have adverse environmental impacts. Considering the broad definition of environment, both impact and causative platform (fig.4) include natural and man-made physical features and historical sites. It is perceived interrelationships between tourism activities, infrastructure, industrial development, and environment sustainability calls for specialized discipline, such as coastal ecology and recreational development, [17]. The impacts are linked to construction of associated infrastructures ranging from low to intensive projects needed for coastal and outdoor recreation. Properly managed tourism can sustain local economies without damaging the environment, protecting and thereby enhancing opportunity for the future [18] as well as respecting the limits imposed by ecological communities [19]. The environment-tourism relationship in any platform must be sustainable tourism. Parks and coastal areas must primarily be defined in terms of sustainable ecosystems. [20]. Tourism aims at providing people with a variety of leisure and recreational activities related satisfaction, which the industry promotes and provides in return for financial reward such activities include travel, shopping, cruising, sun bathing, yachting, and diving, as well as dining and residing in restaurants and hotels. In many coastal areas, tourism is the largest sector of the economy while construction of hotels, apartments, and other tourist infrastructure is becoming the dominant form of development. Tourism activities have far-reaching impacts upon the human (cultural, social) resources of tourist destinations as well as on the physical (vegetation, wildlife, water, etc.) resources, but must be conducted for present tourists and host regions while protecting and enhancing opportunity for the future [21]. In all we strongly identified the use of vehicular and other group movement patterns that have been investigated by [22]. This type of mobility generates attendant environmental waste. We agree that it is environmentally friendly to walk and trek along beaches/coastlines and forest parks.

\subsection{Environmental Impact of Tourism on Coastal Regions of Guangdong Province}

Southeast Asia is an area of extraordinarily high biodiversity. This high diversity in land and sea is a result of three major factors: the overlap of independently - evolved varieties of species, high rates of local speciation, and differentially-high survival rates temporally and spatially heterogeneous habitats [23]. [24] documented that coastal regions can be defined on a transdisciplinary challenge which we considered in utilization and management (1) as a geographic area where land and sea interact through natural processes, but we can also consider it (2) as a zone of economic activity based on the exploitation of coastal and marine resources, (3) as a socio-cultural entity, with specific traditions and values or (4) as an institutional entity with administrative boundaries. This has made the region at large and China specifically, a major tourism destination. Notably, both coastal and interior parts of China show immense prospects for growth in tourism. We identified that, in table 1, based on our single multiplier impact ratings, Shenzhen, Guangzhou, Zhuhai and Dongguan were rated high. This was attributed to multiple activity base and geographical position, not only factors generated by tourism factors in the region. It is agreed and related efforts to help coastal regional authorities inculcate ecosystem-based management approaches in sustaining coastal resources with attention to pressures and population influx. Notably, modifications to the coastal environment due to tourism tend to degrade environmental resources. On the other hand, this can also contribute to protection of the coastal environmental due to increased awareness of the need for better maintenance and conservation of the coastal environment. A biodiversity conservation approach generates awareness and becomes a tool to finance the ecological conservation of coastal regions at large, especially the natural tourism potential, which is applicable in the study region. The negative impact of tourism occurs when the pressure from visitors (level of users) becomes greater than the environment's ability to cope (carrying capacity) within natural acceptable limits of change.

This pressure concept is often referred to as the "Wear and Tear Effect" of tourism facilities and coastal resources. Negative environmental impacts on man - made and natural coastal tourism potential may be worsened through uncontrolled conventional tourism practices. In the case of coastal regions like the coast of the South China Sea in Guangdong province, enormous pressure leads to coastal and sea erosion, increased pollution, effluent discharges into the sea, loss of natural habitats, increased pressure on endangered species, and increased vulnerability of coastal wetland plant species. Further negative impact includes stress and strain on water resources and compels the local people or communities to scramble for coastal resources, especially critically scarce resources. [25] supported that our field impact inventory as in fig. 4 and table 1 are critically experiencing: 1) increased pressure from automobile emissions, resulting in significant air pollution and other wastes; 2) increased pressure from use of natural/manmade facilities resulting to anthropogenic influence such as sand beach quality; 3) population increase and concentration leading to overcrowding and degradation of coastal resources; 4) significant deterioration and alteration of biodiversity and natural ecosystem; 5) increase in environmental management, insecurity, uncontrolled building, and change to the natural landscape (like sand dunes); 6) An increase in noise, air, water, solid wastes pollution; 7) degradation of aesthetic 
quality due to litter from cannel flooding and careless disposal like polyethylene, paper, cigarette packs, beer bottles/cans of drinks; 8) decrease microbiological ecological quality and general environmental hygiene - caused by increased refuse and contamination; 9) serious impact on plant species through flower collection, cutting and trampling.

\subsection{Impact of Trampling and Waste Generation by Tourists in the Coastal Region}

Trampling is a human induced factor, [26]; identified in this study and its impact that is predominant on coastal vegetation and soil environment as shown in table 4 . The damages done by trampling and associated outdoor activities by tourist do results in alteration of ecosystems. Field observation confirmed tourists collecting branches and flowers along the tourist destinations in the area. These observations underscore the direct negative environmental impact of tourism there. Trampling affects coastal vegetation and soil, and generates further impact on tidal flat in fauna [27]. These activities by tourists are described as "recreational disturbance". The impact of trampling was considered low at most sites but fragile ecosystems like the littoral active zone have been documented as heavily impacted. [28]. However, [29] confirmed that the potential damage due to trampling has mostly been studied in the short term (two years). We followed used routes marked on tourist maps to observe the practical effect of trampling as associated with tourism such as shoot/flower collection and off-path hiking. These activities impact the least vulnerable plant communities. Waste is associated with human activities generally as most field (tourist hot spots) environments were littered with plastic materials, food wrappers, and all kinds of drinks bottles. However, the placement of waste bins is a way of dealing with this problem, but some tourists still continue to litter rather than put waste in such bins. [30] documented that beaches and coastlines are impacted more by litter pollution, and however, the presence of waste collectors and waste management trucks in most of the spots we visited was encouraging. Observed impacts are linked to construction of associated infrastructure ranging from simple to intensive projects needed for coastal and outdoor recreation. Based on this observation, it is evident that coastal regions have attracted outdoor enthusiasts and tourists for some time now as a result of available coastal tourism facilities. The coastal region is currently experiencing a rapid increase in development of infrastructures and in urban development. Tourist destinations include an amalgam of industries such as transportation, accommodation, food and beverage services, recreation, entertainment, and travel agencies [31]; [32]. Much of the discussion on sustainable development and tourism has been in the context of the environment in which tourism occurs [33] [34]. There is an argument that tourism preference could be accounted for, to some extent, by global climate change, especially as with regard to tourism destination preferences.

\section{Conclusion}

This multidisciplinary study provides a good understanding of the long term, immediate benefits and natural potential of coastal and environmental properties along the South China Sea in Guangdong province. The environmental impact of tourism results in modifications that becomes relevant for harmonized local, regional and national authorities for the development of appropriate strategies and updated tourism management techniques to achieve sustainable coastal/forest ecosystems. Further investigation is required to evaluate the annual and seasonal economic impact at the district and regional level in order to build major tourism - related industry profiles and assess their impact on the provincial economy. This is paramount and strategic in terms of the post Olympics China, industrial output, employment, and income and taxation. This paper strongly suggests that there should be outlined appropriate actions and strategies and responsive adoption from various government levels as implemented in Canada. Furthermore, there should be regulation and control, and attention paid to the concepts of fragile ecosystem and sensitive areas, in all areas of land use and coastal developmental planning where tourism plays a major role in the economy.

\section{Acknowledgments}

This study was supported by two key research programs of Guangdong Province (2005A30402003, 2006A36702003) and China Scholarship Council Beijing Award

\section{References}

[1] United Nations Environmental Programs (UNEP) (www.uneptie.org/pc/tourism) (http://www.uneptie.org/pc/tourism/library/home.htm) - webp Planning and managing ed.age: recreation and Tourism: Impacts of Tourism. Visited on the 2008/December.

[2] Pearce, D. G.; Kirk, R. M. (1986): Carrying capacities for coastal tourism. Industry and Environment (UNEP Paris) 9(1), 3-7

[3] Dimanche, F., M.E. Havitz et al. (1991). "Testing and involvement profile scale in the context of selected recreational and tourists activities" Journal of Leisure Research 23(1): 51-66.

[4] Kozak M, Rimmington M. (1998). Benchmarking: destination attractiveness and small hospitality business performance. International Journal of Contemporary

[5] Davenport John and Julia L. Davenport (2006) The impact of tourism and personal leisure transport on coastal environments: A review: Estuarine, Coastal and Shelf Science 67. Elsevier

[6] Leones, J., B. Colby, and K. Crandell. (1998). Tracking expenditure of the elusive nature tourists of Southeastern Arizona. Journal of Travel research 36: 56-61.

[7] Burger, J., (2002) Tourism and ecosystems. In: Douglas, I. (Ed.), Causes and Consequences of Global Climate Change. Encyclopedia of Global Environmental Change, vol. 3. John Wiley \& Sons, Ltd, Chichester, pp. 597e609. 
[8] Gormsen, E. (1981): The spatio-temporal development of international tourism, attempt at a centre-periphery model. Etudes \& Mémoires 55, Centre des Hautes Etudes Touristiques, Aix-en- Provence, 150-169 (Burger 2002)

[9] Gormsen, E. (1988): Tourism in Latin America, spatial distribution and impact on regional change. Applied Geography and Development 32, 65-80

[10] Kreth, R. (1985): Some problems arising from the tourist boom in Acapulco and the difficulties in solving them. Mainzer Geograpische Studien 26, 47-59 Hospitality Management 10(5): 184-188.Kreth (1985)

[11] Uthoff, D. (1996): From traditional use to total destruction. Forms and extent of economic utilization in the Southeast Asian Mangroves. Natural Resources and Development 43/44, 58-94.

[12] Dronkers J., de Vries I. (1999) Integrated coastal management: the challenge of transdisciplinarity. Journal of Coastal Conservation 5, 97-102. 99. Doi: 10.1007/BF02802745

[13] Dillman, Don A. (1978) Mail and telephone surveys - The Total Design Method. New York, NY: Wiley and Sons.

[14] Mike Woods and Suzette Barta (2002): Estimating Impacts of Tourism Events: Methodology and a Case Study - National Extension Tourism Conference: "Changing Faces - Changing Places. University of Michigan Traverse City, Michigan

[15] Barta, Suzette, Woods, Mike D., Trzebiatowski, Susan, and Cain, Derek, (2002) "The Economic Impact of Special Olympics Oklahoma on the Economy of Stillwater, OK." Oklahoma Cooperative Extension Service, AE-02135,

[16] McCune, B., and J. B. Grace, (2002). Analysis of ecological communities. MjM Software Design, Gleneden beach, Oregon.

[17] Frankenberg, D., Pomeroy, L.R., Bahr, L. \& Richardson, J. (1971). Coastal ecology and recreational development. In The Georgia coast: issues and options for recreation (ed. C.D. Clement), II, 1-49. The Conservation Foundation, Washington, D.C

[18] World Tourism Organization. 1993. Sustainable Tourism Development: Guide for Local Planners. Madrid: WTO. Southern Africa 19(1): 123-141.

[19] Payne, R. (1993). Sustainable tourism: Suggested indicators and monitoring techniques. In Tourism and Sustainable Development: Monitoring, Planning, Managing, ed. 1993: $154-5$

[20] Woodley, S. (1993). Tourism and sustainable development in parks and protected areas. In Tourism and Sustainable Development: Monitoring, Planning and Managing ed. 1993: 94).

[21] World Tourism Organization. 1993. Sustainable Tourism Development: Guide for Local Planners. Madrid: WTO. Southern Africa 19(1): 123-141.
[22] Brodhead, J.M. \& Godfrey, D.J. (1977) Off-road vehicle impact in Cape Cod National Seashore; disruption and recovery of dune vegetation. Int. J. Biometeor. 21, 299-306.

[23] McManus, J.W. (1985).Marine speciation, tectonics, and sealevel changes in Southeast Asia. Proceedings of the 5th International Coral Reef Congress, Tahiti. 4:133-138.

[24] [12] Dronkers J., de Vries I. (1999) Integrated coastal management: the challenge of transdisciplinarity. Journal of Coastal Conservation 5, 97-102. 99. Doi: 10.1007/BF02802745

[25] Bhaskar Nath (1998) Environmental Management in Practice: Managing the Ecosystem, Routledge Publishers Bhaskar Nath (1998)

[26] Burden R. F. and P. F. Randerson (1972). Quantitative Studies of the Effects of Human Trampling on Vegetation as an Aid to the Management of Semi-Natural Areas, British Ecological Society

[27] Chandrasekara W.U., Frid C.L.J. (1997) Effects of human trampling on tidalflat infauna. Aquatic conservation-Marine and Freshwater Ecosystems 7, 299-311 Conserv, 71, 223-230 (Chandrasekara, and Frid (1997).

[28] Heath, R. (1987). Impact of trampling and recreational activities on the littoral active zone - a literature review. Univ. of Port

[29] Roovers P, K. Verheyen, M. Hermy, and H. Gulinck (2004): Experimental trampling and vegetation recovery in some forest and heathland communities. Applied Vegetation Science, BIOONE Online Journals.

[30] Bowman D, Manor-Samsonov N., Golik A., (1998) Dynamics of litter pollution on Israeli Mediterranean beaches: a budgetary, litter flux approach. Journal of Coastal Res., 14, $418-432$

[31] Poonyth D, Barnes JI, Suich H, Monamati M. (2002). Satellite and resource accounting as tools for

[32] Smith and Massieu, 2005, pp. 865- 866). Much of the discussion on sustainable development and tourism has been in the context of the environment in which tourism occurs (Eagles 1994;

[33] Eagles, P.F.J. (1994) Understanding the market for sustainable tourism. In Linking Tourism, the Environment and Sustainability, ed. S.F. McCool and A.E. Watson, pp. 23-33. Ogden, UT: USDA (General Technical Report INT-GTR-323).

[34] McCool, S.F. (1994). Linking tourism, the environment, and concepts of sustainability: Setting the stage. In Linking Tourism, the Environment and Sustainability, ed. S.F. McCool and A.E. Watson, pp. 3-7. Ogden, UT: USDA (General Technical Report INT-GTR-323). 